\title{
Demeclocycline in the treatment of the syndrome of inappropriate secretion of antidiuretic hormone
}

\author{
W H PERKS, E H WALTERS, ${ }^{1}$ I P TAMS, AND K PROWSE \\ From the Department of Respiratory Physiology, City General Hospital, Stoke-on-Trent, \\ Staffordshire, UK
}

\begin{abstract}
Fourteen patients with the syndrome of inappropriate secretion of antidiuretic hormone (SIADH) have been treated with demethylchlortetracycline (demeclocycline) $1200 \mathrm{mg}$ daily. In 12 patients the underlying lesion was malignant. The serum sodium returned to normal $(>135 \mathrm{mmol} / \mathrm{l})$ in all patients after a mean of 8.6 days (SD $\pm 5 \cdot 3$ days). Blood urea rose significantly from the pretreatment level of $4 \cdot 2 \pm 2 \cdot 3 \mathrm{mmol} / 1$ to $10 \cdot 1 \pm 5 \cdot 1 \mathrm{mmol} / 1$ at ten days $(P<0 \cdot 001)$. The average maximum blood urea was $13.4 \pm 6.8 \mathrm{mmol} / \mathrm{l}$. In four patients the urea rose above $20 \mathrm{mmol} / \mathrm{l}$, and in two of these demecyocycline was discontinued because of this rise. The azotaemia could be attributed to a combination of increased urea production and a mild specific drug-induced nephrotoxicity. Discontinuation of demeclocycline in six patients led to a fall in serum sodium, in one case precipitously, and return of the urea towards normal levels. Demeclocycline appears therefore to be an effective maintenance treatment of SIADH, and the azotaemia that occurs is reversible and probably dose dependent.
\end{abstract}

The syndrome of inappropriate secretion of antidiuretic hormone (SIADH) has become increasingly recognised as a treatable cause of stupor and confusion in patients with a wide variety of diseases (De Troyer and Demanet, 1976). Until recently treatment has been directed at correcting the electrolyte abnormalities by fluid restriction, which may be difficult in a confused patient (Perks et al, 1976), or treatment of the primary condition. Several case reports (Cherrill et al, 1975; De Troyer and Demanet, 1975; Perks et al, 1976; Perks et al, 1978) have suggested that demeclocycline is effective in SIADH. Demeclocycline interferes with the action of antidiuretic hormone on the renal collecting ducts and thus induces nephrogenic diabetes insipidus (Singer and Rotenberg, 1973). Recent publications (De Troyer, 1977; Forrest et al, 1978) have recorded the efficacy of demeclocycline in correcting hyponatraemia in SIADH. Impaired renal function has been reported in one patient during treatment (De Troyer, 1977). We report our experience of 14 patients with SIADH treated with demeclocycline and of the drug's effect on renal function.

'Present address: c/o Western (Chest) Hospital, Shirley, Southampton.

\section{Methods}

Fourteen patients with a diagnosis of SIADH based on the criteria of De Troyer and Demanet (1976) have been treated with demeclocycline over the period 1976-8). All but two patients had inoperable malignant disease. Patient 1 had undiagnosed miliary tuberculosis, and patient 7 developed persistent hyponatraemia after a chest infection (table 1). All were treated with demeclocycline (demethylchlortetracycline), $1200 \mathrm{mg}$ daily, in divided doses by mouth. Some were treated first by fluid restriction, but all were maintained on a free fluid intake as the serum sodium returned towards normal.

Serum electrolytes, urea, creatinine, osmolarity, and packed cell volume (PCV) were measured before and during treatment. In seven patients 24-hour urine collections were obtained for volume, urea, and electrolyte estimations.

The demeclocycline was discontinued in seven patients. Patient 5 died three days later from her primary disease. The remaining six patients were reinvestigated after a mean of 60 days (range 7143) from discontinuation of demeclocycline.

The results were analysed statistically using paired $t$ tests and analysis of correlation. 
Table 1 Details of 14 patients with SIADH before treatment with demeclocycline

\begin{tabular}{|c|c|c|c|c|c|c|c|c|}
\hline Case No & Diagnosis & Age & Sex & $\begin{array}{l}\text { Plasma } \\
\text { sodium } \\
\text { mmol/l }\end{array}$ & $\begin{array}{l}\text { Plasma } \\
\text { bicarbonate } \\
\text { mmol/l }\end{array}$ & $\begin{array}{l}\text { Blood } \\
\text { urea } \\
\text { mmol/l }\end{array}$ & $\begin{array}{l}\text { Serum } \\
\text { osmolarity } \\
\text { mosmol/kg }\end{array}$ & $\begin{array}{l}\text { Urine } \\
\text { osmolarity } \\
\text { mosmol/kg }\end{array}$ \\
\hline $\begin{array}{r}1 \\
2 \\
3 \\
4 \\
5 \\
6 \\
7 \\
8 \\
9 \\
10 \\
11 \\
12 \\
13 \\
14\end{array}$ & $\begin{array}{l}\text { Tuberculosis } \\
\text { Carcinoma bronchus } \\
\text { Carcinoma bronchus } \\
\text { Carcinoma bronchus } \\
\text { Carcinoma bronchus } \\
\text { Carcinoma bronchus } \\
\text { Pneumonia } \\
\text { Mesothelioma } \\
\text { Carcinoma bronchus } \\
\text { Carcinoma bronchus } \\
\text { Chronic lymphatic leukaemia } \\
\text { Carcinoma bronchus } \\
\text { Carcinoma bronchus } \\
\text { Carcinoma bronchus } \\
\text { Mean } \\
\text { 土Standard Deviation }\end{array}$ & $\begin{array}{r}62 \\
62 \\
46 \\
52 \\
81 \\
70 \\
77 \\
56 \\
72 \\
51 \\
53 \\
44 \\
63 \\
66 \\
61 \\
+11\end{array}$ & $\begin{array}{l}\mathbf{M} \\
\mathbf{M} \\
\mathbf{F} \\
\mathbf{M} \\
\mathbf{F} \\
\mathbf{M} \\
\mathbf{F} \\
\mathbf{M} \\
\mathbf{F} \\
\mathbf{M} \\
\mathbf{F} \\
\mathbf{F} \\
\mathbf{M} \\
\mathbf{F}\end{array}$ & \begin{tabular}{r|}
118 \\
118 \\
111 \\
115 \\
118 \\
119 \\
120 \\
119 \\
120 \\
119 \\
112 \\
111 \\
117 \\
99 \\
116 \\
$+\quad 6$
\end{tabular} & $\begin{array}{r}21 \\
25 \\
26 \\
22 \\
30 \\
33 \\
21 \\
24 \\
24 \\
33 \\
31 \\
27 \\
\pm 5\end{array}$ & $\begin{array}{r}6 \cdot 7 \\
1 \cdot 2 \\
1 \cdot 0 \\
4 \cdot 3 \\
1 \cdot 7 \\
3 \cdot 7 \\
6 \cdot 7 \\
5.9 \\
7.0 \\
1 \cdot 7 \\
7 \cdot 0 \\
2 \cdot 7 \\
2.9 \\
4 \cdot 5 \\
4 \cdot 1 \\
+2 \cdot 2\end{array}$ & $\begin{array}{r}262 \\
244 \\
266 \\
248 \\
257 \\
256 \\
253 \\
252 \\
268 \\
271 \\
261 \\
251 \\
231 \\
217 \\
253 \\
+14\end{array}$ & $\begin{array}{r}642 \\
663 \\
418 \\
604 \\
365 \\
567 \\
671 \\
418 \\
904 \\
870 \\
569 \\
558 \\
416 \\
602 \\
590 \\
+154\end{array}$ \\
\hline
\end{tabular}

Table 2 Comparative data before, during, and after treatment with demeclocycline.

\begin{tabular}{|c|c|c|c|c|c|}
\hline & \multirow{2}{*}{$\begin{array}{l}\text { No of } \\
\text { patients }\end{array}$} & \multirow{2}{*}{$\begin{array}{l}\text { Before } \\
\text { treatment }\end{array}$} & \multicolumn{2}{|c|}{ During treatment } & \multirow{2}{*}{$\begin{array}{l}\text { After } \\
\text { treatment }\end{array}$} \\
\hline & & & At 10 days & $\begin{array}{l}\text { Minimum } \\
\text { value }\end{array}$ & \\
\hline Serum sodium mmol/l,mean \pm SD & 14 & $\begin{array}{r}118 \\
\pm \quad 8\end{array}$ & $\begin{array}{r}138 \\
\pm \quad 7\end{array}$ & - & - \\
\hline Serum sodium mmol/1 where demeclocycline discontinued, mean $\pm S D$ & 6 & $\begin{array}{r}122 \\
\pm \quad 7\end{array}$ & $\begin{array}{r}138 \\
\pm \quad 6\end{array}$ & - & $\begin{array}{r}125 \\
\pm \quad 7\end{array}$ \\
\hline Urine sodium mmol $/ 1$, mean $\pm S D$ & 7 & $\begin{array}{r}54 \\
\pm 24\end{array}$ & $\begin{array}{r}29 \\
\pm 21\end{array}$ & $\begin{array}{r}17 \\
\pm 17\end{array}$ & - \\
\hline Urine urea serum urea ratio (uu/su), mean \pm SD & 9 & $\begin{array}{r}59 \\
\pm 46\end{array}$ & $\begin{array}{r}22 \\
\pm 10\end{array}$ & $\begin{array}{r}19 \\
\pm \quad 9\end{array}$ & - \\
\hline
\end{tabular}

\section{Results}

During treatment with demeclocycline all patients showed an improvement in level of consciousness. The data before, during, and after treatment are summarised in table 2 . The serum sodium concentration returned to normal $(>135 \mathrm{mmol} / \mathrm{l})$ in all patients after a mean of $8 \cdot 6 \pm 5 \cdot 3$ days. The figure shows the response of the serum sodium to treatment. There was no relation between the rate of improvement of the serum sodium and the 24-hour fluid intake in the nine patients for whom adequate data were available. Both urinary sodium concentrations $(P<0.01)$ and urine urea-serum urea ratios $(P<0.05)$ fell significantly with treatment (table 2).

Discontinuation of demeclocycline in six patients produced a fall in serum sodium from $138 \mathrm{mmol} / 1(\mathrm{SD} \pm 6 \mathrm{mmol} / \mathrm{l})$ to $125 \mathrm{mmol} / 1(\mathrm{SD} \pm$ $7 \mathrm{mmol} / \mathrm{l})(\mathrm{P}<0.05)$. In patient 10 discontinuation of demeclocycline caused a precipitous fall in serum sodium over seven days from $138 \mathrm{mmol} / 1$ to $112 \mathrm{mmol} / 1$ with return of confusion and stupor. When the demeclocycline was restarted the serum sodium again returned to normal. $\mathrm{He}$ was main-

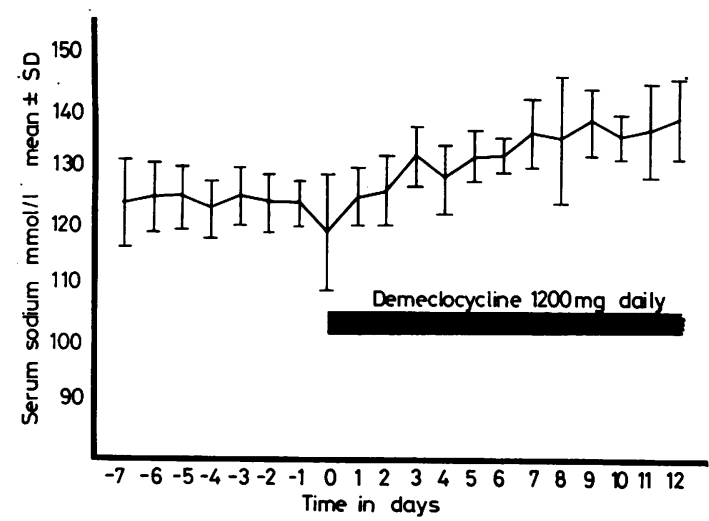

Response of the serum sodium to treatment with demeclocycline, $1200 \mathrm{mg}$ daily, in 14 patients with SIADH.

tained at home on demeclocycline for one year until his death from bronchial carcinoma. Details have been recorded by Perks et al (1976).

Renal function before and during treatment with demeclocycline is shown in table 3 . There was a significant rise in both blood urea $(P<0.001)$ 
Table 3 Renal function before, during, and after treatment with demeclocycline

\begin{tabular}{|c|c|c|c|c|c|}
\hline & \multirow{2}{*}{$\begin{array}{l}\text { No of } \\
\text { patients }\end{array}$} & \multirow{2}{*}{$\begin{array}{l}\text { Before } \\
\text { treatment }\end{array}$} & \multicolumn{2}{|c|}{ During treatment } & \multirow{2}{*}{$\begin{array}{l}\text { After } \\
\text {-treatment }\end{array}$} \\
\hline & & & At 10 days & $\begin{array}{l}\text { Maximum } \\
\text { value }\end{array}$ & \\
\hline Blood urea $\mathrm{mmol} / \mathrm{l}$, mean $\pm \mathrm{SD}$ & 14 & $\begin{array}{r}4 \cdot 2 \\
\pm 2 \cdot 3\end{array}$ & $\begin{array}{r}10 \cdot 1 \\
\pm \quad 5 \cdot 1\end{array}$ & $\begin{array}{r}13 \cdot 4 \\
\pm \quad 6 \cdot 8\end{array}$ & - \\
\hline Blood urea mmol/1 where demeclocycline discontinued, mean $\pm \mathrm{SD}$ & 6 & $\begin{array}{r}4 \cdot 1 \\
\pm 2 \cdot 1\end{array}$ & $\begin{array}{r}7 \cdot 8 \\
\pm \quad 2 \cdot 1\end{array}$ & $\begin{array}{r}10 \cdot 4 \\
\pm \quad 5 \cdot 3\end{array}$ & $\begin{array}{r}4 \cdot 9 \\
\pm 4 \cdot 2\end{array}$ \\
\hline Serum creatinine $\mu$ mol $/ 1$, mean $\pm \mathrm{SD}$ & 13 & $\begin{array}{r}78 \cdot 5 \\
\pm 20 \cdot 9\end{array}$ & $\begin{array}{r}106 \cdot 5 \\
\pm \quad 54 \cdot 0\end{array}$ & $\begin{array}{r}125 \cdot 8 \\
+\quad 52 \cdot 5\end{array}$ & - \\
\hline Serum creatinine mmol/l where demeclocycline discontinued, mean $\pm \mathrm{SD}$ & 5 & $\begin{array}{r}79 \cdot 8 \\
\pm 23 \cdot 1\end{array}$ & $\begin{array}{r}99 \cdot 8 \\
\pm 15 \cdot 5\end{array}$ & $\begin{array}{r}121 \cdot 0 \\
\pm 19 \cdot 5\end{array}$ & $\begin{array}{r}82 \cdot 8 \\
\pm 28 \cdot 3\end{array}$ \\
\hline Packed cell volume (PCV), mean \pm SD & 10 & $\begin{array}{r}0.38 \\
\pm 0.05\end{array}$ & $\begin{array}{r}0.37 \\
\pm \quad 0.05\end{array}$ & 一 & - \\
\hline 24-hour urinary urea excretion mmol/24 h, mean $\pm S D$ & 7 & $\begin{array}{r}194 \\
\pm 136\end{array}$ & $\begin{array}{r}271 \\
\pm 66\end{array}$ & $\begin{array}{r}404 \\
\pm 127\end{array}$ & - \\
\hline
\end{tabular}

and creatinine $(P<0.05)$ at ten days in patients treated with demeclocycline, although the rise in the former was disproportionately greater. In the six patients in whom the demeclocycline was discontinued the blood urea and creatinine returned towards normal $(\mathrm{P}<0.005$ and $\mathrm{P}<0.01$ respectively). In four patients the blood urea rose above $20 \mathrm{mmol} / 1$ (normal range $2 \cdot 5-5 \cdot 8 \mathrm{mmol} / \mathrm{l}$ ) on treatment and in a further four patients above $10 \mathrm{mmol} / \mathrm{l}$. This azotaemia led to stopping demeclocycline in two patients. There was no significant relation between the rise in blood urea and the fluid intake in the nine patients in whom adequate data were available, and no change occurred in packed cell volume (PCV). There was a significant rise $(p<0.01)$ in 24-hour urinary urea excretion on demeclocycline. Serial measurements of creatinine clearance in two patients (4 and 14) showed a progressive fall from $98 \mathrm{ml} / \mathrm{min}$ to $84 \mathrm{ml} / \mathrm{min}$ and from $40 \mathrm{ml} / \mathrm{min}$ to $24 \mathrm{ml} / \mathrm{min}$ respectively.

\section{Discussion}

In the 14 patients with SIADH the serum sodium returned to normal during treatment with demeclocycline, confirming the observations of De Troyer (1977) and Forrest et al (1978). Demeclocycline acts by inducing nephrogenic diabetes insipidus (Castell and Sparks, 1965; Roth et al, 1967; Singer and Rotenberg, 1973), which accounts for the fall in urine sodium concentration and urinary urea-serum ratio in our patients. At a subcellular level there is evidence of impairment of both the generation and action of cyclic adenosine monophosphate (cyclic AMP), the intracellular mediator of vasopressin (Singer and Rotenberg, 1973; Dousa and Wilson, 1974). The rate of return of the serum sodium to normal appears to be unrelated to fluid intake. Fluid restriction, therefore, may be unnecessary even in the early stages of treatment. As fluid restriction is relatively easy to manage for short periods, however, it may be used in conjunction with demeclocycline during the first few days of treatment. A free fluid intake may then be permitted. It appears from our results that the effects of demeclocycline on the serum sodium are reversible and that cessation of treatment results in a fall in serum sodium to pretreatment levels.

Azotaemia has been reported with the use of demeclocycline in congestive heart failure (Cox et al, 1977) and cirrhosis (Carrilho et al, 1977). Forrest et al (1978) presented data on seven patients and reported a modest rise in blood urea nitrogen. They commented that noteworthy azotaemia was not observed in any of their patients. De Troyer (1977) reported a moderate rise in blood urea and creatinine levels during treatment, but the rise was not statistically significant. Three of seven patients developed a raised urea and two a raised creatinine. In one case there was a renal metastasis and in the second no cause for the impaired renal function was found. A druginduced nephrotoxicity was therefore invoked as a cause of this renal impairment.

In our series of 14 patients both blood urea and creatinine rose significantly on demeclocycline. The mean blood urea rose to a maximum level of more than three times the pretreatment value. These changes could not be attributed to volume depletion as there was no significant increase in PCV treatment, and in addition there was no relation between fluid intake and rate of rise in blood urea. There was, however, a significant rise in 24-hour urinary urea excretion, probably as a result of the antianabolic effect of demeclocycline (Shils, 1963). There was also a rise in serum 
creatinine, although not as pronounced as the rise in urea, and, in the two patients where serial measurements were made, a fall in creatinine clearance. This azotaemia could therefore be attributed to the dual effect of excess urea production and a specific drug-induced nephrotoxicity.

The present study suggests that the adverse effects of demeclocycline on renal function are more important than previously suggested (Forrest et al, 1978). In four patients the blood urea rose above $20 \mathrm{mmol} / 1$ and in two patients the demeclocycline was discontinued as a result (with the redevelopment of hyponatraemia). Forrest et al (1978) used doses of demeclocycline ranging from 600 to $1200 \mathrm{mg}$ daily while De Troyer (1977), as in our study, used $1200 \mathrm{mg}$ daily for all patients. This higher dose may therefore be associated with an increased likelihood of impaired renal function. The effects of demeclocycline on renal function therefore appear to be both reversible and dose dependent, and it may be worthwhile to treat the condition with an initial daily dose of $1200 \mathrm{mg}$ and, as the electrolytes return to normal, decrease the dose by titrating it against the serum sodium. In any case, the risk of azotaemia is a small price to pay for ease of patient management, particularly in a terminal illness.

We thank Drs $\mathbf{M}$ Green, $\mathbf{K} \mathbf{M}$ Citron, L A Liversedge, and W van't Hoff for allowing us to report details of their patients, and Miss S Perry and Mrs B Cartlidge for secretarial help.

\section{References}

Carrilho, F, Bosch, J, Arroyo, V, Mas, A, Viver, J, and Rodes, J (1977). Renal failure associated with demeclocycline in cirrhosis. Annals of Internal Medicine, 87, 195-197.

Castell, D O, and Sparks, H A (1965). Nephrogenic diabetes insipidus due to demethylchlortetracycline hydrochloride. Journal of the American Medical Association, 193, 237-239.
Cherrill, D A, Stote, R M, Birge, J R, and Singer, $L$ (1975). Demeclocycline treatment in the syndrome of innapropriate antidiuretic hormone secretion. Annals of Internal Medicine, 83, 654-656.

Cox, M, Guzzo, J, Morrison, G, and Singer, I (1977). Demeclocycline and therapy of hyponatraemia. Annals of Internal Medicine, 86, 113.

De Troyer, A (1977). Demeclocycline: treatment for syndrome of inappropriate antidiuretic hormone secretion. Journal of the American Medical Association, 237, 2723-2726.

De Troyer, A, and Demanet, J C (1976). Clinical, biological, and pathogenic features of the syndrome of inappropriate secretion of antidiuretic hormone. Quarterly Journal of Medicine, 45, 521-531.

De Troyer, A, and Demanet, J C (1975). Correction of antidiuresis by demeclocycline. New England Journal of Medicine, 293, 915-918.

Dousa, T P, and Wilson, D M (1974). Effect of demethylchlortetracycline on cellular action of antidiuretic hormone in vitro. Kidney International, 5, 279-284.

Forrest, J N, Cox, M, Hong, C, Morrison, G, Bia, M, and Singer, I (1978). Superiority of demeclocycline over lithium in the treatment of chronic syndrome of inappropriate secretion of antidiuretic hormone. New England Journal of Medicine, 298, 173-177.

Perks, W H, Crow, J, and Green M (1978). Mesothelioma associated with the syndrome of inappropriate secretion of antidiuretic hormone. American Review of Respiratory Disease, 117, 789-794.

Perks, W H, Mohr, P, and Liversedge, L A (1976). Demeclocycline in the treatment of the inappropriate ADH syndrome. Lancet, 2, 1414.

Roth, H, Becker, K L, Shalhoub, R J, and Katz, S (1967). Nephrotoxicity of demethylchlortetracycline hydrochloride. Archives of Internal Medicine, 120, 433-435.

Shils, M E, (1963). Renal disease and metabolic effects of tetracycline. Annals of Internal Medicine, 58, 389-408.

Singer, I, and Rotenberg, D (1973). Demeclocyclineinduced nephrogenic diabetes insipidus: in-vivo and in-vitro studies. Annals of Internal Medicine, 79, 679-683.

Requests for reprints to: $\mathrm{Dr}$ W H Perks, Department of Respiratory Physiology, City General Hospital, Newcastle Road, Stoke-on-Trent, Staffordshire. 